
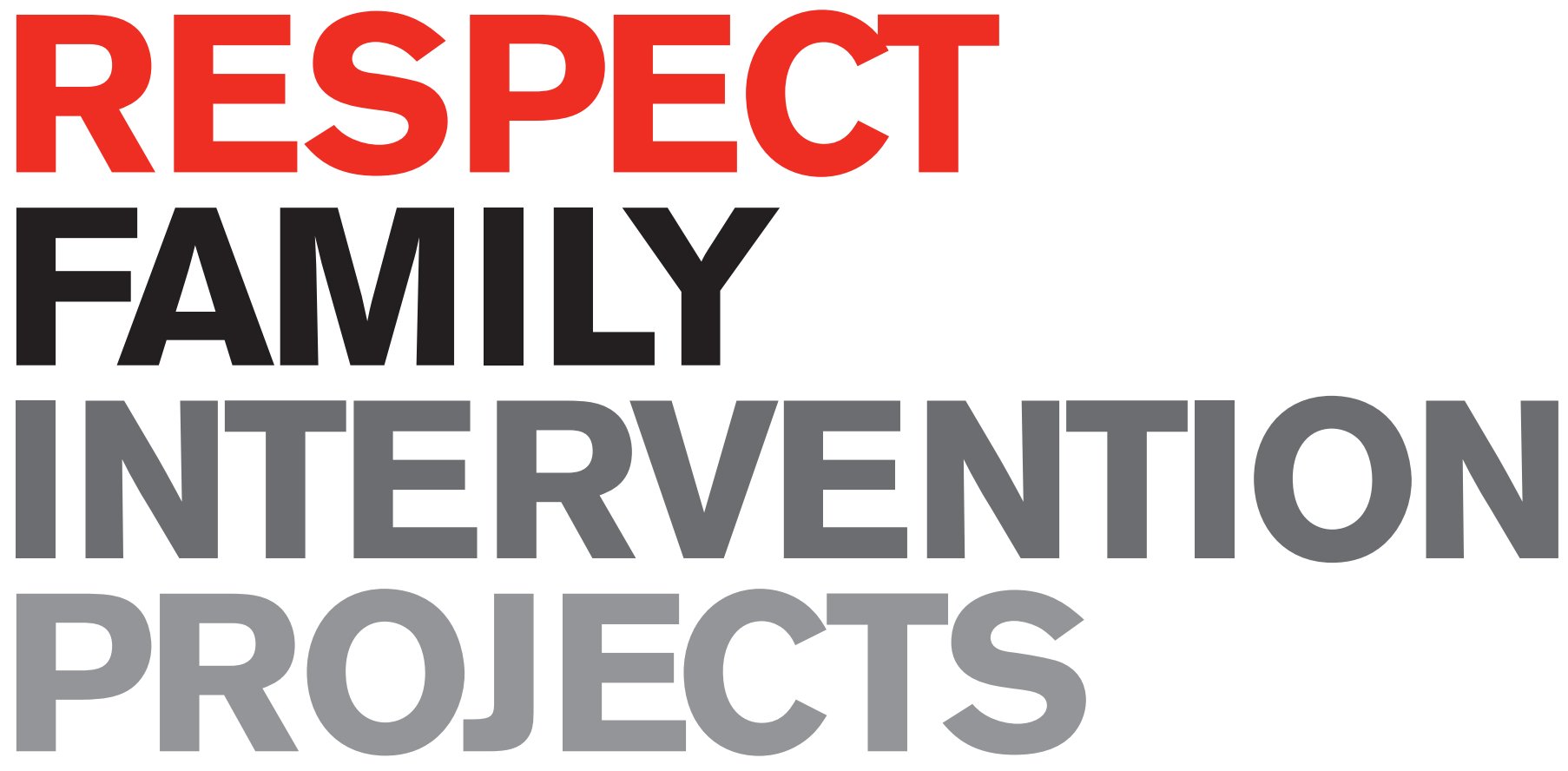



\section{FAMILY INTERVENTION}

PROJECTS

\section{Introduction}

There are many reasons why we should be proud of the families and the communities we have now. Most people take their responsibilities to their families and to other people seriously and try hard to raise their children well. But there are still intractable problems with the behaviour of some families, behaviour which can make life a misery for others.

The Respect Action Plan confirmed the Government's commitment to step up action on anti-social behaviour but also pledged to tackle the root causes with the same rigour and determination. Key to this is the establishment of a national network of family intervention projects.

Developing long-term, multi-agency strategies on problem families to improve the way public services deal with them is central to the success of any family intervention project. All agencies must have a common approach to challenge bad behaviour and clear objectives that all partners agree on.

Where family intervention projects are already up and running around the country, they have shown to be very effective in reducing the anti-social behaviour caused by problem families. These projects have also had great success in preventing homelessness, providing routes back to settled housing as well as improving school attendance.

Family intervention projects are difficult schemes to run and hard to get right but they pay enormous dividends to many people when they work as they should. 


\section{The issue}

In some communities there are a small number of highly problematic families that account for a disproportionate amount of anti-social behaviour. Although much has been done to tackle these problem families, it is clear that we need to go further; for their sake and the sake of the wider community.

Sometimes these families have multiple problems that require multiple solutions. But we need those multiple solutions delivered in an effective way - one that adds up to a change in the behaviour of all members of the household.

Many of these families have severe problems and are damaging themselves and their children, as well as those around them. Problems for the children include:

- disrupted education through frequent changes of school and poor attendance

- disrupted access to health services leading to crisis intervention rather than prevention

- constant changes of address affecting children's ability to make lasting friendships or get involved in regular activities

- living in wholly unsuitable accommodation, with an increased likelihood of being exposed to risk

- involvement in anti-social behaviour, often escalating into crime and

- an increased risk of children being looked after within the statutory care system.

\section{Respect action}

Based on evidence, we now know that this small number of families need an intensive, persistent and, if necessary, coercive approach. The Respect programme will establish a national network of family intervention projects. These projects will support and challenge families to increase their motivation to change their behaviour. This new approach will consider the needs of whole families and balance these with the needs of the community. This will ensure that the destructive behaviour which is so often passed from generation to generation, blighting not only these families but entire communities, is effectively tackled for the first time.

This work is very much targeted at those whose antisocial behaviour is threatening their tenancies, is putting their children at risk or is likely to lead to them facing significant enforcement action.

\section{What do the projects do?}

These projects use a twin-track approach which includes help for families to address the causes of their behaviour, alongside supervision and enforcement tools to provide them with the incentives to change.

Family intervention projects use intensive tailored action with supervision and clear sanctions to improve the behaviour of persistently anti-social households. A key worker 'grips' the family, the causes of their poor behaviour and the agencies involved with them, to deliver a more co-ordinated response. This involves a multi-agency approach to ensure all the necessary services are included, for example:

- social services

- health departments

- children's trusts

- education departments

- youth offending teams

- criminal justice and

- police services. 


\section{Objectives}

The primary objective of family intervention projects is to stop the anti-social behaviour of families and restore safety to their homes and to the wider community.

These projects also tackle the causes of poor behaviour which involve issues such as drug and alcohol misuse, poor health, domestic violence, worklessness and debt. As a result these projects also deliver other objectives such as preventing homelessness, enabling families to sustain tenancies and helping achieve the five Every Child Matters outcomes for children and young people.

\section{Key features}

The intervention delivered by these projects goes beyond traditional tenancy support, multi-agency case conferences and key working.

Key features of the approach include:

\section{Worst families first}

A focus on the most problematic families who are persistently perpetrating anti-social behaviour and are at risk of losing their homes or of other significant enforcement action.

\section{Sanctions are key}

The threat of sanctions or use of sanctions provides both a way of curbing bad behaviour and also a lever for persuading people to accept and co-operate fully with the offers of help.

\section{Gripping the problem - getting to the real causes}

A 'whole family' approach which considers the needs of the whole household and assesses the underlying problems driving the family's behaviour in order to identify which services need to be involved. Part of the solution is the parenting element. This ranges from the family worker providing intense one-to-one help to referring parents to structured, high-quality courses.

\section{Gripping the family - changing behaviour}

A contract between the family and the project which sets out the changes in behaviour that are expected, support that will be provided and sanctions that will be imposed if behaviour does not improve.

The contract is the tool which establishes what is expected by each party. It should be explicit in setting acceptable standards of behaviour and any sanctions that may arise if a family fails to comply. It should also identify the types of support to be offered and should be reviewed and updated as necessary. Template contracts for use are available at www.respect.gov.uk

\section{Gripping all the other agencies}

A lead key worker who co-ordinates activity and whose persistent and assertive working style ensures families stick to agreements in the contract and change behaviour. The lead worker also needs to make sure that only the right agencies are involved and that they meet their obligations to deliver services.

All agencies need to sign up to working to the same ends - stopping the anti-social behaviour of the whole family before they can move on to other issues.

\section{Referrals}

Referrals might be made by statutory agencies, housing associations, voluntary sector organisations or even by families themselves. Referrals must be accepted into the projects from anti-social behaviour teams or their equivalent.

\section{Impact}

- The Dundee families project has an $84 \%$ success rate with the most difficult families

- Sheffield Hallam University has recently conducted an evaluation of six family support projects in the North West. This study has found:

- an 84\% improvement in school attendance

- an $80 \%$ reduction in the threat of possession action

- that the projects are strong on their primary objective of reducing incidents and complaints about anti-social behaviour - an $85 \%$ reduction in anti-social behaviour was recorded. 


\section{Types of intervention}

There are some projects around the country that are already working with the families to be targeted by family intervention projects, and although they all have similar objectives and features they do vary in who they help and the level of problems they are presented with.

There are three distinct models of intervention which can be applied:

\section{Intensive outreach programme to families in their own homes}

Families are visited by project staff within their own home who provide/refer to structured individual and family sessions to work with the family on a range of issues identified as causing their anti-social behaviour.

\section{Intensive outreach programme to families in dispersed accommodation}

Families are provided with a non-secure tenancy by the project. Staff visit and provide/refer to structured individual and family sessions to work with the family on a range of issues identified as causing their anti-social behaviour. If the family complies with interventions and behaviour improves sufficiently then the tenancy can be made secure.

\section{Intensive support programme in supervised accommodation \\ Families in this type of provision receive 24-hour support and supervision from staff in accommodation provided by the project. Families are likely to be involved in many structured sessions complemented by daily unstructured observation. If the family complies with interventions and behaviour improves sufficiently then they will be able to move into one of the above.}




\section{The Addison family}

Christine lived with her four children on an estate in $\mathrm{X}$ as a council tenant. Christine was under threat of eviction for non-payment of rent and anti-social behaviour complaints from other residents. The children had three different fathers - none of whom were living in the property. Men were regularly seen visiting the property, and it was listed as a bail address for two recently released offenders.

Two of her four children had ASBOs and one was in a young offenders' institution. All four children were either truanting or on long-term exclusions from school. Her youngest son at age seven had been seen smoking. Her eldest child showed evidence of self-harm. Christine herself was suffering from mental health problems. Care proceedings on her two youngest children were likely to commence.

The property and the family were the source of persistent anti-social behaviour - the property was used for constant visits and noisy gatherings late at night and children from across the estate would use it to hang around when they should have been in school during the day. Various acquaintances were using Christine's home to deal drugs and carry out car repairs on the grass at the front. Residents across the estate were subject to abuse, threats and vandalism to their property, and they lived in fear.

When the family intervention project first became involved, Christine's home was in a considerable state of disrepair - there were holes in the floors and walls, there was no working fridge or cooker, and the children had to boil eggs in the kettle. Rubbish accumulated in all the rooms including children's bedrooms where vermin had moved in.

Numerous agencies were trying to engage with Christine and her family. At the time of the project's involvement there were around 20 agencies including the youth offending team, community mental health team, social services, education welfare officers, police, anti-social behaviour team, housing services, Connexions service, probation service, debt advice service, educational psychologist, etc. Christine and her children neither kept appointments with these professionals nor opened the door when they came to the house. Christine admitted to the project that, while she wanted help, she 'played them off against each other'.

Christine and her family were costing services well in excess of $£ 250,000$ per year.

The family intervention project:

- refused to go away

- used sanctions as a way to make them engage

- gripped the family as a whole - with one persistent, determined, unflinching key worker

- ensured that all the services were working to agreed goals - to stop the anti-social behaviour and deal with its underlying causes

- set targets and boundaries for the family to change behaviour and laid down clear consequences for non-compliance and

- helped Christine to be a parent and a member of the community. 


\section{EXAMPLE OF A FAMILY INTERVENTION \\ PROGRAMME FAMILY CONTRACT}

This is an example of an actual contract. The names have been changed.

\begin{tabular}{|c|c|c|}
\hline Family Name: & Brown & Ref No: 159 \\
\hline Key Worker: & Emma Stevens & Date: 14.01 .06 \\
\hline Case Manager: & Ben Adamson & \\
\hline Aim Of Placement: & \multicolumn{2}{|c|}{$\begin{array}{l}\text { To establish the family in a family intervention project } \\
\text { dispersed tenancy. } \\
\text { To address all areas of concern relating to anti-social behaviour, including } \\
\text { parenting. } \\
\text { To sign the tenancy over to the family once the terms of this contract have } \\
\text { been met. }\end{array}$} \\
\hline Type Of Placement: & \multicolumn{2}{|c|}{ Dispersed accommodation } \\
\hline 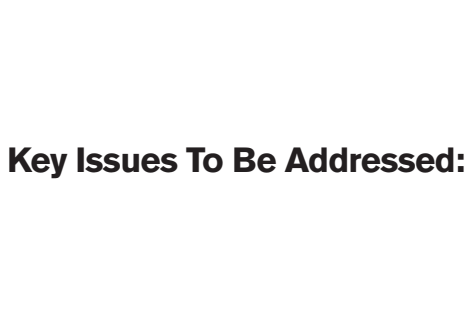 & \multicolumn{2}{|c|}{$\begin{array}{l}\text { - Parenting } \\
\text { - Neighbour conflict } \\
\text { - Maintenance of tenancy } \\
\text { - Appropriate behaviour and language within the community }\end{array}$} \\
\hline Identified Family Strengths: & \multicolumn{2}{|c|}{$\begin{array}{l}\text { - Willingness to co-operate and make appropriate use of support/advice } \\
\text { given by agencies involved } \\
\text { - Willingness to take on board concerns/issues raised by professionals, as } \\
\text { well as others }\end{array}$} \\
\hline
\end{tabular}


Family contract

\begin{tabular}{|c|c|c|c|c|c|c|}
\hline $\begin{array}{l}\text { Agreed } \\
\text { tasks }\end{array}$ & $\begin{array}{l}\text { Methods } \\
\text { to be used }\end{array}$ & $\begin{array}{l}\text { What will be } \\
\text { done, by whom }\end{array}$ & $\begin{array}{l}\text { When and } \\
\text { where it } \\
\text { will take } \\
\text { place }\end{array}$ & $\begin{array}{l}\text { Desirable } \\
\text { changes }\end{array}$ & Timescale & Sanctions \\
\hline $\begin{array}{l}\text { Planned } \\
\text { Home Visits } \\
\text { to Elsa } \\
\text { (parent). }\end{array}$ & One to one. & $\begin{array}{l}\text { Work will focus } \\
\text { on: } \\
\text { - positive } \\
\text { parenting } \\
\text { - neighbour } \\
\text { conflict } \\
\text { - boundary } \\
\text { setting } \\
\text { - appropriate use } \\
\text { of sanctions } \\
\text { - care and } \\
\text { maintenance of } \\
\text { tenancy } \\
\text { - rights and } \\
\text { responsibilities } \\
\text { as a tenant } \\
\text { Emma Stevens } \\
\text { (key worker). }\end{array}$ & $\begin{array}{l}4 \text { times per } \\
\text { week. } \\
\text { Elsa's home. }\end{array}$ & $\begin{array}{l}\text { - Elsa and } \\
\text { her family to } \\
\text { settle into the } \\
\text { community } \\
\text { with no } \\
\text { recurrence } \\
\text { of previous } \\
\text { anti-social } \\
\text { behaviour. } \\
\text { - Elsa to } \\
\text { maintain her } \\
\text { tenancy in a } \\
\text { satisfactory } \\
\text { manner. } \\
\text { - Elsa to be } \\
\text { in control of } \\
\text { her children's } \\
\text { behaviour. }\end{array}$ & $\begin{array}{l}\text { Ongoing, } \\
\text { with } 6 \text { weekly } \\
\text { reviews. }\end{array}$ & $\begin{array}{l}\text { Early FIP } \\
\text { Review called } \\
\text { with family } \\
\text { members and } \\
\text { all involved } \\
\text { agencies } \\
\text { to address } \\
\text { problems } \\
\text { and consider } \\
\text { future action. } \\
\text { Housing } \\
\text { Department } \\
\text { will consider } \\
\text { appropriate } \\
\text { necessary } \\
\text { action, ABC } \\
\text { - ASBO. } \\
\text { Social } \\
\text { Services will } \\
\text { consider } \\
\text { appropriate } \\
\text { necessary } \\
\text { action, } \\
\text { parenting } \\
\text { contract } \\
\text { - parenting } \\
\text { order. }\end{array}$ \\
\hline $\begin{array}{l}\text { Elsa can } \\
\text { also access } \\
\text { support/ } \\
\text { advice } \\
\text { from Key } \\
\text { workers by } \\
\text { telephoning } \\
\text { the Project } 7 \\
\text { days a week } \\
\text { at any time. }\end{array}$ & & & & & & \\
\hline
\end{tabular}




\section{EXAMPLE OF A FAMILY INTERVENTION PROGRAMME FAMILY CONTRACT}

Family contract (continued)

\begin{tabular}{|c|c|c|c|c|c|c|}
\hline $\begin{array}{l}\text { Agreed } \\
\text { tasks }\end{array}$ & $\begin{array}{l}\text { Methods } \\
\text { to be used }\end{array}$ & $\begin{array}{l}\text { What will be } \\
\text { done, by whom }\end{array}$ & $\begin{array}{l}\text { When and } \\
\text { where it } \\
\text { will take } \\
\text { place }\end{array}$ & $\begin{array}{l}\text { Desirable } \\
\text { changes }\end{array}$ & Timescale & Sanctions \\
\hline $\begin{array}{l}\text { Work with } \\
\text { children. }\end{array}$ & $\begin{array}{l}\text { Group } \\
\text { Work. }\end{array}$ & $\begin{array}{l}\text { Issues to be } \\
\text { addressed: } \\
\text { Neighbour } \\
\text { conflict } \\
\text { 1. Vandalism. } \\
\text { 2. Dealing } \\
\text { with difficult } \\
\text { personalities. } \\
\text { 3. Respect for } \\
\text { others and } \\
\text { their property. } \\
\text { Appropriate } \\
\text { use of } \\
\text { language at } \\
\text { home, school } \\
\text { and in the } \\
\text { community. } \\
\text { 1. Use of } \\
\text { language, } \\
\text { good and bad. } \\
\text { 2. How you } \\
\text { present } \\
\text { yourself. } \\
\text { 3. Giving and } \\
\text { receiving } \\
\text { respect. } \\
\text { Emma Stevens } \\
\text { (Key Worker). } \\
\text { Alan Petrie } \\
\text { (Social Worker). }\end{array}$ & $\begin{array}{l}\text { Once a } \\
\text { week at } \\
\text { the Young } \\
\text { Peoples } \\
\text { Resource } \\
\text { Centre. }\end{array}$ & $\begin{array}{l}\text { - For the } \\
\text { children to } \\
\text { settle into the } \\
\text { community } \\
\text { with no } \\
\text { recurrence } \\
\text { of previous } \\
\text { anti-social } \\
\text { behaviour. } \\
\text { - For the } \\
\text { children to } \\
\text { form more } \\
\text { appropriate } \\
\text { friendships. }\end{array}$ & & $\begin{array}{l}\text { Police will } \\
\text { consider } \\
\text { appropriate } \\
\text { necessary } \\
\text { action, police } \\
\text { warning } \\
\text { - possible } \\
\text { criminal } \\
\text { charges. } \\
\text { Education } \\
\text { will consider } \\
\text { appropriate } \\
\text { necessary } \\
\text { action, ABC } \\
\text { - exclusion. }\end{array}$ \\
\hline
\end{tabular}


Family contract (continued)

\begin{tabular}{|c|c|c|c|c|c|c|}
\hline $\begin{array}{l}\text { Agreed } \\
\text { tasks }\end{array}$ & $\begin{array}{l}\text { Methods } \\
\text { to be used }\end{array}$ & $\begin{array}{l}\text { What will be } \\
\text { done, by whom }\end{array}$ & $\begin{array}{l}\text { When and } \\
\text { where it } \\
\text { will take } \\
\text { place }\end{array}$ & $\begin{array}{l}\text { Desirable } \\
\text { changes }\end{array}$ & Timescale & Sanctions \\
\hline $\begin{array}{l}\text { Work with } \\
\text { Charmaine } \\
\text { (eldest } \\
\text { daughter). }\end{array}$ & $\begin{array}{l}\text { One to one. } \\
\text { One to one. }\end{array}$ & $\begin{array}{l}\text { Alcohol } \\
\text { awareness } \\
\text { sessions to } \\
\text { cover; effects of } \\
\text { alcohol, alcohol } \\
\text { misuse and } \\
\text { consequences } \\
\text { for self, family, } \\
\text { community. } \\
\text { Shona } \\
\text { Williams } \\
\text { (Drug \& Alcohol } \\
\text { Support worker) } \\
\text { - Use of } \\
\text { language. } \\
\text { - Developing } \\
\text { activities and } \\
\text { interests. } \\
\text { - Appropriate } \\
\text { friendships. } \\
\text { Farrah } \\
\text { Muhammed } \\
\text { (Youth Resource } \\
\text { Worker). } \\
\text { - Planning for } \\
\text { the future: } \\
\text { identifying skills } \\
\text { and strengths, } \\
\text { potential } \\
\text { training } \\
\text { opportunities. } \\
\text { Jack Williams } \\
\text { (Job Centre Plus). }\end{array}$ & $\begin{array}{l}\text { Once a } \\
\text { week at } \\
\text { Family } \\
\text { Intervention } \\
\text { Project or } \\
\text { outwith as } \\
\text { appropriate. }\end{array}$ & $\begin{array}{l}\text { For Charmaine } \\
\text { to ensure her } \\
\text { alcohol intake } \\
\text { is managed, } \\
\text { ensuring } \\
\text { there is no } \\
\text { detrimental } \\
\text { impact on } \\
\text { herself or } \\
\text { others. } \\
\text { For Charmaine } \\
\text { to develop } \\
\text { positive } \\
\text { relationships } \\
\text { with her peer } \\
\text { group and } \\
\text { others. To } \\
\text { experience and } \\
\text { develop healthy } \\
\text { interests and } \\
\text { productive } \\
\text { leisure time. } \\
\text { For Charmaine } \\
\text { to undertake } \\
\text { employment } \\
\text { training with } \\
\text { a view to } \\
\text { securing } \\
\text { employment. }\end{array}$ & & $\begin{array}{l}\text { Early FIP } \\
\text { review called if } \\
\text { necessary. }\end{array}$ \\
\hline
\end{tabular}




\section{EXAMPLE OF A FAMILY INTERVENTION PROGRAMME FAMILY CONTRACT}

Family contract (continued)

\begin{tabular}{|c|c|c|c|c|c|c|}
\hline $\begin{array}{l}\text { Agreed } \\
\text { tasks }\end{array}$ & $\begin{array}{l}\text { Methods } \\
\text { to be used }\end{array}$ & $\begin{array}{l}\text { What will be } \\
\text { done, by whom }\end{array}$ & $\begin{array}{l}\text { When and } \\
\text { where it } \\
\text { will take } \\
\text { place }\end{array}$ & $\begin{array}{l}\text { Desirable } \\
\text { changes }\end{array}$ & Timescale & Sanctions \\
\hline $\begin{array}{l}\text { Planned } \\
\text { home visits } \\
\text { to family. }\end{array}$ & $\begin{array}{l}\text { Family } \\
\text { Session. }\end{array}$ & $\begin{array}{l}\text { - To follow up } \\
\text { any issues/ } \\
\text { difficulties } \\
\text { which arise } \\
\text { from the group. } \\
\text { - Living together } \\
\text { as a family: } \\
\text { roles, helping } \\
\text { each other, } \\
\text { showing } \\
\text { respect. } \\
\text { - Living in the } \\
\text { community: } \\
\text { our family as } \\
\text { neighbours. } \\
\text { Emma Stevens } \\
\text { (Keyworker) } \\
\text { with input as } \\
\text { required from } \\
\text { Alison } \\
\text { Williams } \\
\text { (ASB Worker) } \\
\text { and } \\
\text { Alan Petrie } \\
\text { (Social Worker). }\end{array}$ & $\begin{array}{l}\text { Family home } \\
\text { - weekly. }\end{array}$ & $\begin{array}{l}\text { For the family } \\
\text { to have respect } \\
\text { for themselves, } \\
\text { each other } \\
\text { and their local } \\
\text { community. }\end{array}$ & & $\begin{array}{l}\text { Immediate } \\
\text { review called } \\
\text { if support } \\
\text { refused. }\end{array}$ \\
\hline $\begin{array}{l}\text { Work with } \\
\text { Mark } \\
\text { (youngest } \\
\text { son). }\end{array}$ & One to one. & $\begin{array}{l}\text { - Sessions to } \\
\text { address weekly } \\
\text { feedback } \\
\text { from school } \\
\text { re. behaviour/ } \\
\text { progress. } \\
\text { Lucy Dyer } \\
\text { (Education } \\
\text { Support Worker). }\end{array}$ & $\begin{array}{l}\text { Once } \\
\text { a week } \\
\text { session at } \\
\text { the school. }\end{array}$ & $\begin{array}{l}\text { For Mark to } \\
\text { attend school, } \\
\text { maintain good } \\
\text { behaviour } \\
\text { and progress } \\
\text { through school } \\
\text { curriculum. }\end{array}$ & & $\begin{array}{l}\text { Education } \\
\text { will consider } \\
\text { appropriate } \\
\text { necessary } \\
\text { action, ABC } \\
\text { - exclusion. }\end{array}$ \\
\hline
\end{tabular}


Family contract (continued)

\begin{tabular}{|c|c|c|c|c|c|c|}
\hline $\begin{array}{l}\text { Agreed } \\
\text { tasks }\end{array}$ & $\begin{array}{l}\text { Methods } \\
\text { to be used }\end{array}$ & $\begin{array}{l}\text { What will be } \\
\text { done, by whom }\end{array}$ & $\begin{array}{l}\text { When and } \\
\text { where it } \\
\text { will take } \\
\text { place }\end{array}$ & $\begin{array}{l}\text { Desirable } \\
\text { changes }\end{array}$ & Timescale & Sanctions \\
\hline $\begin{array}{l}\text { Weekend } \\
\text { and Evening } \\
\text { cover. }\end{array}$ & $\begin{array}{l}\text { Telephone } \\
\text { contact and } \\
\text { home visits. }\end{array}$ & $\begin{array}{l}\text { Work should } \\
\text { focus on giving } \\
\text { Elsa support } \\
\text { with any difficult } \\
\text { behaviour } \\
\text { displayed by the } \\
\text { children. } \\
\text { Emma Stevens } \\
\text { (Keyworker) } \\
\text { In addition, } \\
\text { Community } \\
\text { Support Team } \\
\text { to respond to } \\
\text { any crisis issues } \\
\text { re childcare/ } \\
\text { protection. }\end{array}$ & $\begin{array}{l}\text { Elsa's home. } \\
\text { Saturday } \\
\text { and Sunday } \\
\text { Evenings. }\end{array}$ & & & \\
\hline
\end{tabular}

To be signed by all parties

\begin{tabular}{l|l|l}
\hline Name & Title & Date \\
\hline Elsa Brown & Parent & 14.01 .06 \\
\hline Ben Adamson & Senior Project Worker & 14.01 .06 \\
\hline Emma Stevens & Keyworker & 14.01 .06 \\
\hline Alison Williams & ASB Worker & 14.01 .06 \\
\hline Alan Petrie & Social Worker & 14.01 .06 \\
\hline PC Jim Boyd & Police & 14.01 .06 \\
\hline Jack Williams & Job Centre Plus & 14.01 .06 \\
\hline Farah Muhammed & Youth Resource Worker & 14.01 .06 \\
\hline Lucy Dyer & $\begin{array}{l}\text { Education Support } \\
\text { Worker }\end{array}$ & 14.01 .06 \\
\hline
\end{tabular}




\section{Resources}

Template contracts for use are

available at www.respect.gov.uk

Family Intervention Project

Referral Form - Housing Provider

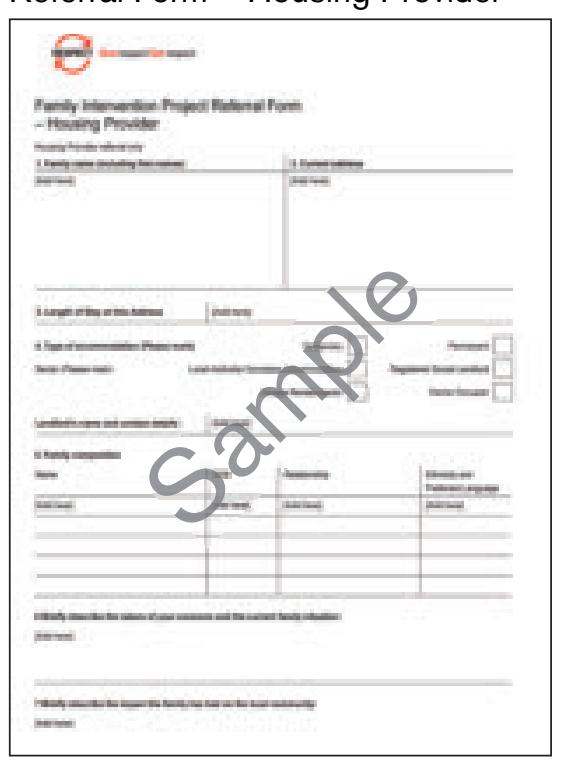

Family Intervention Project

Generic Referral Form

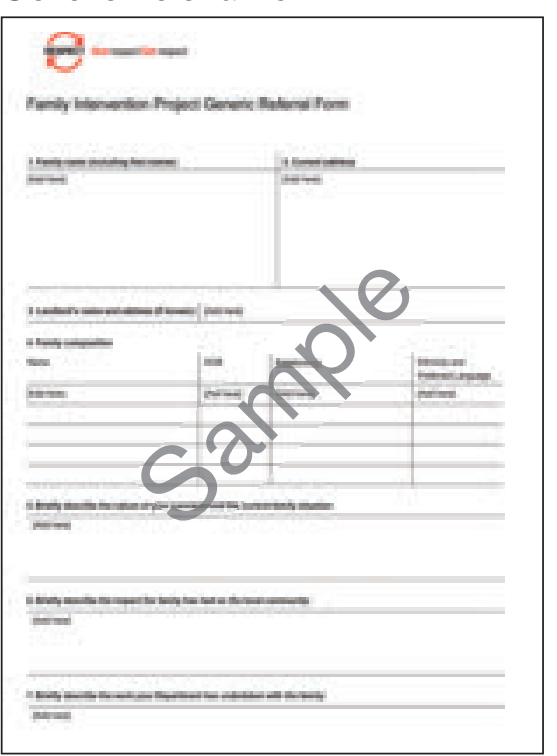

Family Intervention Project

Referral Form - Social Services

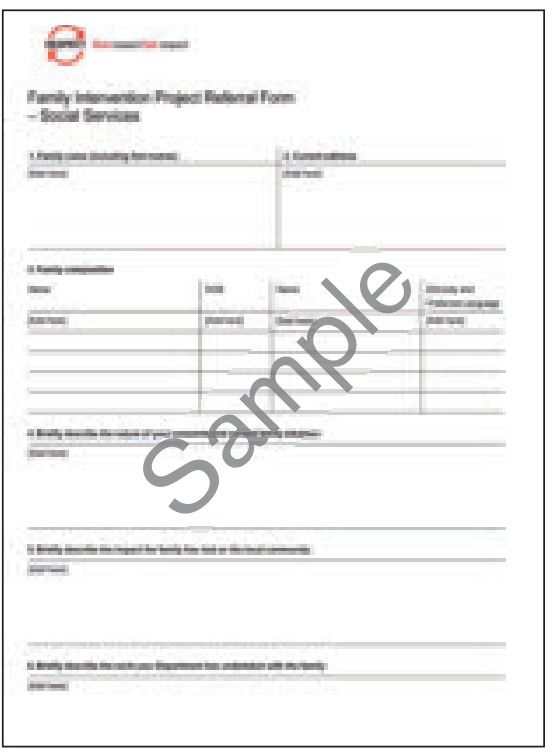



Contact

For further information please visit www.respect.gov.uk

Product code - RTF - FIP 